\title{
Creation and Divine Providence in Plotinus
}

Christopher Isaac Noble and Nathan M. Powers ${ }^{1}$

[This is the penultimate version of a paper that appears in A. Marmodoro and B. Prince (eds.), Creation and Causation in Late Antiquity (Cambridge, 2015), p. 51-70.]

\section{Introduction}

According to Plato's Timaeus our world was constituted and arranged in the best possible way by a divine craftsman (the Demiurge). Plato represents the Demiurge as being guided by his own planning or calculation (logismos, Tim. 30b, 34a-b) about how to bring about maximally good order in the cosmos he produces. Indeed, it seems that the Demiurge's causal power with respect to our cosmos is labelled 'foresight' or 'providence' (pronoia, Tim. 30b-c) precisely to reflect the claim that benevolent divine planning is explanatory of various features of the physical world. ${ }^{2}$ Among Platonists of the early empire, planning was widely understood (on Plato's authority) to be an integral aspect of the Demiurge's creative activity. Plotinus, however, dissents sharply from the earlier Platonist tradition on this point. He argues that divine reason (nous) cannot make plans of any sort concerning the physical cosmos, or indeed entertain any thoughts whatsoever about physical realities. This leaves Plotinus with the challenge of developing an alternative account of how divine intellectual activity determines and guarantees - as he affirms it does — a 'providentially' optimal world-order.

The bulk of this paper will discuss Plotinus' case against the view that the cosmos is the product of Demiurgic planning and the alternative account of divine providence that he proposes in that view's stead. But it will be useful to begin by briefly focusing attention on the picture of divine planning presented in the Timaeus, because Plotinus' dissenting story about providence can plausibly be taken to be motivated by a desire to resolve tensions internal to Platonism that arise in connection with this picture.

\footnotetext{
${ }^{1}$ We wish to thank audiences at the LMU-München and at a conference at the CNRS Centre Jean Pépin in Paris (organized by Meryem Sebti and Daniel de Smet) for valuable discussion of this paper, and Peter Adamson for helpful written comments on an early draft.

${ }^{2}$ Cf. Tim. 44c, 45a-b.
} 
In the Timaeus, the Demiurge is initially confronted with pre-cosmic stuff in a disorderly state; and since he is good, he desires to make everything that exists (including this stuff) as good as possible. To this end, he decides to construct a cosmos endowed with soul and intelligence (30b-c); and since the cosmos is to be a living being, he selects the "complete living being" as the appropriate intelligible model after which to fashion the $\operatorname{cosmos}(27 \mathrm{~d}-29 \mathrm{a}, 30 \mathrm{c}-31 \mathrm{~b}){ }^{3}$ In making these and other arrangements for the structure and constitution of the world and its parts, both the Demiurge and the 'lesser gods' - to whom he delegates the creation of mortal beings are guided by their thoughts about how to bring about the best cosmic order and well-designed organisms. In Plato's own account there is some obscurity about the respective contributions of the intelligible model and of god's planning activity to particular features of the sensible cosmos. ${ }^{4}$ Still, it is clear is that basic to Plato's conception of the divine planning are (i) that it is thought about the sensible cosmos, (ii) that this thought involves the discovery of means to ends, and (iii) that it is directed towards prospective states of affairs (as its description as 'forethought' suggests). Plotinus, however, does not accept that the divine thought responsible for cosmic order could have any of these features, and accordingly denies that the cosmos is the product of planning.

Plotinus' case against divine planning rests upon a set of assumptions that hail in part from the Timaeus itself and its tradition of interpretation. Among these, of particular importance are the Platonist identifications of the Demiurge with a divine intellect and of the intelligible model that the Demiurge looks to with the Platonic Forms. ${ }^{5}$ These two interpretative claims appear to have been widely regarded as compatible with the thesis that god plans certain features

\footnotetext{
${ }^{3}$ The "complete living being" that the Demiurge uses as a model is apparently the Form of Animal, which is "complete" in virtue of being the whole of the kind animal, rather than any of the specific animal kinds that are its parts (Tim. 30c). The Timaeus leaves unresolved how the design of the physical cosmos might reflect the population of the intelligible world more generally.

${ }^{4}$ In the Timaeus, some features of the cosmos evidently reflect the Demiurge's desire to instantiate what is already given in his model, but planning is also required to work out how features of the model are to be best approximated in a physical medium; other features here may well not represent attempts to copy any feature of the model. This left wide room for variation in ancient interpretations of the Demiurge; at one extreme, the early Stoics were inspired by the Timaeus to identify the benevolence of their divine craftsman entirely with his providential reasoning about the best disposition for the cosmos, even though they dismissed the notion that the cosmos has an intelligible model (see Powers 2013).

${ }^{5}$ The identification of the Forms (collectively) with the Demiurge's model finds support in the causal role other Platonic texts accord to a wide array of Forms.
} 
of the sensible cosmos. ${ }^{6}$ By contrast, Plotinus reaches the conclusion that, once other Platonic commitments are taken properly into account, the identification of the Demiurge with a divine intellect and of the model for the sensible cosmos with the Forms leaves no place for divine planning in cosmology (or, indeed, for the Demiurge to have any intentions whatsoever regarding the sensible world). Faced with this result, Plotinus proposes that all references to planning in the Timaeus are to be taken metaphorically, as Plato's way of indicating that the cosmos, since it is as good as it can be, accords with the arrangement at which a divine designer would have arrived, had the cosmos in fact been the product of planning. ${ }^{7}$

\section{The Framework for Plotinus’ Views About Providence}

Before turning to Plotinus' arguments against the view that the Demiurge engages in planning the cosmos, it will be helpful to briefly orient ourselves to the place of the Demiurge and his creation in Plotinus' metaphysics, and to articulate the further commitments that serve as the basis for those arguments.

Plotinus maintains that the whole of reality derives from a perfectly simple first principle identified as 'the One' or 'the Good'. This first principle, the One, generates a divine Intellect (nous) that thinks the Platonic Forms, which also constitute its substance, so that Plotinus' divine Intellect is, like Aristotle's, a self-thinker. This Intellect in turn generates Soul. Finally, one particular soul, the so-called World-Soul (and specifically, its nutritive faculty, Nature),

\footnotetext{
${ }^{6}$ Middle Platonist authors widely adopt the Timaeus' characterizations of the Demiurge as planning the cosmos and its soul, often repeating Plato's own examples without any evident qualms: see e.g. Philo of Alexandria, De op. mund. 16 ff.; Apuleius, De Platone 1.8, 1.10; Atticus, fr. 6.6-9 des Places; Plutarch, De an. procr. 1025a-f, 1027a, De sera 550d-e; and Alcinous, Didask. 12.2-3, 14.4; cf. Galen Hipp. et Plat. 7.5.21. The state of our evidence makes it difficult to determine whether the absence of explicit references to planning in other authors reflects dissent on this point. For providence in Middle Platonism, see Dragona-Monachou 1994, Mansfeld 1999, and Sharples 2003. For Platonists on the Demiurge, see Opsomer 2005.

${ }^{7}$ III.2.14.1-6; V.8.7.36-44; VI.2.21.32-37; VI.7.1.28-32; VI.8.17.1-4; cf. III.2.3.6-9. Plotinus also appears to interpret the claim that Demiurge desires to create because he is without envy (phthonos, Tim. 29e) metaphorically. True to the letter of the Timaeus, he describes the productive activity of intelligible entities as a manifestation of their lack of 'envy' (IV.8.4.1-10; IV.8.6.1-18; V.4.1.34-36). But since, in the cases of his first principle (the One) and of nous, this production involves no desire to produce their product (III.2.2.10-12), Plotinus construes this language in non-intentional terms; cf. his qualifications of the claim that they lack envy (hoion, IV.8.6.12; hôsper, V.4.1.35), his application of this description to a radiant light source (IV.8.4.3-5), and more generally his use of inanimate entities (e.g. fire's warming and snow's cooling) to illustrate the productive activity of intelligible entities (cf. e.g. IV.5.7; V.1.3; V.1.6; V.3.7; V.4.1).
} 
generates the sensible cosmos by producing matter and imparting form to it. At each stage of this causal sequence the producer timelessly generates its product (whole-cloth, as it were) as a necessary outcome of its own essential activity - a causal pattern typically labeled 'emanation' (from Plotinus' images of the product 'flowing from' its cause) or 'double-activity' (with reference to Plotinus' distinction between the energeia that is intrinsic to the cause and the energeia that constitutes the product). In this scheme, the Demiurge is (for Plotinus as for Platonists before him) identified with the divine Intellect; and his role in creating the physical cosmos is mediated by the activity of the World-Soul he creates.

This Plotinian interpretation of the broad structure of Platonist metaphysics represents in certain ways a departure from earlier mainstream Platonist views. Most conspicuously, Plotinus' view that the highest god is a principle prior to divine nous (the One) and his theory of 'emanation' are exceptional. Yet the basic commitments that underlie Plotinus' arguments against divine planning each enjoyed some measure of acceptance among his Platonist predecessors, and the battery of arguments that proceed from them, taken together, present a forceful challenge to the compatibility of divine planning with other Platonist principles. These commitments are as follows:

\section{C1: Two-Worlds Epistemology}

Only Forms can be objects of knowledge; physical realities, with which we are acquainted through sense-perception, are objects of an inferior mode of cognition: mere belief or opinion (doxa).

The locus classicus for this two-worlds epistemology is Plato's account of knowledge and belief in Republic V-VI. According to the argument in Republic V, knowledge (epistêmê) has as its object Forms, whereas opinion (doxa) has as its object sensibles. This epistemic schema is further refined in the simile of the divided line in Republic VI, where Plato designates the cognitive state consisting of the apprehension of intelligible objects as noêsis. ${ }^{8}$ As we shall see below, this epistemological picture raises a difficulty about how divine nous can reflect upon

\footnotetext{
${ }^{8}$ See Rep. 508d, where the soul's apprehension of intelligible objects is designated nous in contrast to doxa of sensible items; and Tim. $27 \mathrm{~d}$ ff. Cf. V.9.7.
} 
how sensible reality should be disposed; for the epistemic states most plausibly attributed to divine nous, knowledge (epistêmê) and understanding (noêsis), are directed solely towards intelligible reality and do not concern the sensible realm at all. ${ }^{9}$

\section{C2: The Perfect Actuality of Divine Nous}

Divine nous is a fully actual self-thinker.

This view of nous owes an obvious debt to the account of divine nous in Metaphysics 12, where Aristotle argues that god is a fully actual self-thinking intellect. But Plotinus cannot reach his conception of divine nous via the strategy Aristotle pursues there, because Aristotle deduces that god has these attributes in a series of arguments built around the common premise that god is the very best thing (a status that does not apply in Plotinus' view to nous, but rather to his highest god, 'the One' or 'the Good'). ${ }^{10}$ Instead, like Aristotle in $D A 3.5$, Plotinus proceeds from the assumption that there must be some nous that knows in full actuality in virtue of its essence; the existence of a nous of this sort is necessary as a cause of the actualization of knowing in merely potential knowers. ${ }^{11}$ While there is some dispute about what the nous of $D A$ III.5 knows and how it relates to the divine nous of Metaphysics 12, for Plotinus the actual nous that is the cause of knowing in us is the divine nous that thinks the Forms, and it is able to serve as a cause for the actualization of knowledge in potential knowers (i.e. souls) precisely because it contains all knowledge in actuality (V.9.4). Moreover, Plotinus contends that nous' possession of knowledge in virtue of its essence implies that the beings it knows are internal to it and, indeed, that nous' knowledge and the beings it knows must be one and the same. For if nous were other than its objects of thought, it would not know in virtue of its essence, but instead be a potential knower brought to actuality by something else (V.9.5.1-10). In this way, Plotinus reaches the

\footnotetext{
${ }^{9}$ Although Aristotle likewise accepts that nous has as its object noêta rather than aisthêta (DA 3.4, 429a13-18), this thesis does not imply a two-worlds epistemology, as the noêta acquired by scientific inquiry are attained via perception and concern aspects of sensible reality (An. post. 2.19).

${ }^{10}$ Aristotle's arguments in Metaphysics 12 are, however, an effective critique against Platonists who identify as the highest god a Demiurge who engages in cosmic planning. Aristotle argues that, since god's activity must be the very best activity, he will engage exclusively in an activity of theoretical contemplation (theôria), and that this activity is wholly devoid of change. Such considerations provide reasons to doubt that the planning of mundane affairs befits the highest divinity; cf. Sedley 2007: 169-71.

${ }^{11}$ For Aristotelian influences on Plotinus' theory of nous, see Menn 2001: 235-39.
} 
view that nous' thought consists in the necessarily complete and comprehensive theoretical contemplation of its own substance (i.e. the Forms). ${ }^{12}$ As we shall see below, this conception of nous will be an important basis for Plotinus' denial of planning to nous. For Plotinus takes planning to involve consideration of non-actual states of affairs; but since nous necessarily thinks only actual beings, it is impossible for it to consider such objects.

\section{C3: The Eternity of the Cosmos}

The physical cosmos had no beginning in time, but is rather the eternal product of nous' activity.

According to the Timaeus, the cosmos had a beginning in time, and there was controversy among ancient Platonists as to whether this claim is to be interpreted literally or not. 'Literalists' about creation maintain that that there is a temporal beginning for the cosmos, whereas 'nonliteralists' about creation maintain that the cosmos is eternal and that Plato speaks as if the cosmos had a temporal beginning solely for expository purposes. ${ }^{13}$ This debate between literalists and non-literalists has implications for divine planning. If planning involves the discovery of means to ends, and the resulting plan can be implemented only after such discovery has occurred, then only literalists about creation in time are well-positioned to claim that the permanent features of the cosmos are planned-whether this planning is conducted by divine nous or by some other divine entity (e.g. the World Soul).

\section{The Case Against Divine Planning}

Plotinus occasionally appeals to $\mathrm{C} 3$ as sufficient to establish the claim that the cosmos is not a product of divine planning: since the cosmos has always existed, there was no time before the cosmos existed when it could have been planned out in advance (III.2.1.15-26, VI.8.17.1-9). But in the opening chapters of Ennead VI.7, How the Multitude of Forms Came into Being and

\footnotetext{
${ }^{12}$ Plotinus also has epistemological grounds for identifying nous with its objects: if they were not the same, nous would not grasp the intelligible things themselves, but rather have mere 'impressions' of them (V.3.5.21-29; cf. V.5.1.50-68); see Emilsson 2007: ch. 3.

${ }^{13}$ For these 'literalist' and 'non-literalist' interpretations, see Baltes 1976 and Sorabji 1983: 268-283.
} 
On the Good, Plotinus offers a far more ambitious and thoroughgoing series of arguments against divine planning. ${ }^{14}$

Plotinus' discussion takes its point of departure from the case of sight and eyes, which figure prominently in the Timaeus as examples of the kinds of abilities and organs that divine reason confers on animals to ensure that they can survive and flourish. ${ }^{15}$ The clear implication of the Timaeus's account is that divine reason, in determining that animals are to have features such as eyes, took into consideration which features would be useful to animals in negotiating their physical surroundings. ${ }^{16}$ Plotinus, however, sharply rejects the implication that the Demiurge literally engages in planning out eyes or any other features of the sensible cosmos. After raising a preliminary query about whether the Demiurge should be thought to confer just sense-organs or also the sense-perceptual capacities that are active through them (VI.7.1.10-21), Plotinus proceeds to offer a set of complementary arguments for the claim that the Demiurge's creative activity cannot involve anything like means-end reasoning about the sensible cosmos.

The first argument (VI.7.1.21 ff.) attacks the idea that divine nous is in a position to think about sensible reality at all. Plotinus begins by granting, for the sake of the argument, that divine nous could engage in discursive reasoning (logismos). This is not (as we shall see below) a supposition that Plotinus himself accepts; but even if it were true, Plotinus says, divine nous could not arrive by such reasoning at conclusions about perceptible, physical items. This is because a reasoner must start from premises about perceptible items in order to reach conclusions about perceptible items; but nous, since it lacks perception, has no access to such premises. ${ }^{17}$ Instead, nous only has intelligible items (noêta) as premises and can, accordingly,

\footnotetext{
${ }^{14}$ For a complementary treatment of Enn. VI.7 that focuses on its engagement with the earlier Platonist and Peripatetic traditions, see Chiaradonna 2015 in this volume.

15 "Did the God [i.e. the Demiurge] or one of the gods [i.e. the 'lesser gods'], when sending souls to birth, put 'lightbearing eyes' in the face and give them the other organs for each of the senses because he foresaw that safety would be ensured in this way, if one saw and heard beforehand and by touching could avoid one thing and pursue another?" (VI.7.1.1-5) Given that Plotinus goes on to deny that the god or gods did in fact confer eyes for the safety of organisms here, it seems preferable not to translate this sentence (pace Armstrong) as an assertion.

${ }^{16}$ Although the explicit rationale in the Timaeus for giving human beings eyes is above all to facilitate the soul's attainment of wisdom (Tim. 47a-c), the proposal that eyes are given for survival is perfectly consonant with the Timaeus' general outlook that bodily structures are designed with a view to the preservation of embodied life (cf. Tim. 33a, 45d-e, 72e-74e).

${ }^{17}$ Thaler 2011: 163-4 takes the argument to be that nous lacks 'aisthêsis' in the sense that it fails to have a general concept of sense-perception, and so, cannot reason about a particular sense modality (e.g. hearing or sight). But Hadot 1988: 197-8 is surely right to take Plotinus' point to be that nous lacks a capacity for sense-perception, and accordingly, lacks appropriate starting points for drawing conclusions about sensible reality (cf. VI.7.1.25-8).
} 
only draw conclusions about noêta. In this argument Plotinus assumes, first and explicitly, that nous does not have the capacity for sense-perception (which is posterior to nous; cf. 'not yet', VI.7.1.24); and, second (albeit implicitly), that noêta do not have as their contents facts about sensible reality. Neither of these assumptions is here defended by Plotinus, but both derive support from (C1), since that view denies to nous epistemic states associated with perception, and holds that nous' proper objects (noêta) are Forms as contrasted with sensible reality.

Having contended that divine nous cannot make plans concerning the physical world because it cannot even entertain thoughts about sensible reality, Plotinus goes on to offer a series of three arguments for the further claim that nous cannot indeed engage in planning (logismos) and foresight (proorasis) about anything whatsoever, since its nature is incompatible with these modes of thought. The series begins with a brief and elliptical argument (VI.7.1.32-35) for the claim that god could have no need of planning and foresight. Planning, he suggests, is useful only for those who are in the epistemically deficient position of not knowing what is to be done. ${ }^{18}$ Similarly, foresight is a cognitive power that would be superseded by something better. ${ }^{19}$ The thrust of these suggestions is that if divine nous had to plan out the cosmos and (in doing so) to foresee future events, this would imply that it is in the position of a practical agent who must have recourse to deliberation; which in turn implies (unacceptably) not only that divine nous is in an inferior epistemic position, but also that it exercises powers whose utility is altogether obviated by its comprehensive theoretical knowledge (see $\mathrm{C} 2$ above).

This second argument prepares the way for two further arguments directly contending that divine cognition is incompatible with the sort of reasoning involved in planning. According to the third argument (VI.7.1.36ff.), planning and forethought necessarily involve consideration of alternative states of affairs; as Plotinus puts it, planning necessarily involves deliberative thoughts of the form "X rather than $Y^{\prime}$ ( or "X in order that not $Y$ "). To arrive at (or possess) such a reasoned preference entails the availability of the two alternatives, $\mathrm{X}$ and $\mathrm{Y}$, for consideration. Plotinus contends, however, that in any case where planning might seem appropriate, there will be only one object (say, X) present within the ambit of divine apprehension. Therefore nous cannot plan. The argument as it stands is severely compressed, and

\footnotetext{
${ }^{18}$ This is a familiar Plotinian point: III.2.1.10-13; IV.3.18.1-7; IV.4.6.10-13; IV.4.12.1-29; IV.8.8.13-16; V.8.4.3638.

${ }^{19}$ Presumably, what is meant is contemplation (theôria); cf. the claim that nature governs the cosmos by contemplation, III.8.1ff.
} 
there is a question as to how best to construe the basis for the contention that for any two genuine alternatives $\mathrm{X}$ and $\mathrm{Y}$, there is in nous only $\mathrm{X}$ or $\mathrm{Y}$ (and not both). On one prominent reading, nous faces no such alternatives because everything in nous is necessary rather than contingent. ${ }^{20}$ We agree that there are no contingencies or open possibilities in nous (indeed, this much is implied by Plotinus' denial of alternatives in nous). However, Plotinus does not deny the existence of alternatives in nous by adverting specifically to modal considerations, and we favour a reading that does not require an additional, implicit appeal to the necessity of nous' thoughtcontents. Recall that on Plotinus' theory of nous, nous' objects of thought are the actual beings it knows (see C2). So nous' thoughts will consist just in thought of what is actual. On this view, nous cannot think ' $\mathrm{X}$, so that not $\mathrm{Y}$ ' or 'there would have been $\mathrm{Y}$, if not $\mathrm{X}$ ' for the simple reason that unrealised alternatives (Y's) - precisely insofar as they are unrealised —would be what potentially was (or is or will be); and nous thinks only actual beings (X's). The actuality of divine thought thus precludes its entertaining alternatives and so precludes planning.

In his fourth argument (VI.7.1.45 ff.), Plotinus continues to develop the contrast between nous' thought and deliberative forethought by observing that all the beings of which nous can be aware are wholly and simultaneously present to it. So there are, for nous, no prospective (i.e., not yet realized) states of affairs to be fore-seen or pre-planned; this much is implied by the complete actuality of nous (see C2). Nonetheless, Plotinus vindicates a special sense in which nous might be said to exercise foresight (as he affirms it does, ln. 42-43), claiming that 'the future' is already present in nous in the sense that it comes to be later in time not in nous, but "in another" (i.e. the sensible world) "as if it had been planned in advance" (ln. 49-52). Thus, nous 'foresees' the future just insofar as it knows once and for all the intelligible counterparts of those things that come into existence earlier and later in the sensible world. ${ }^{21}$

\footnotetext{
${ }^{20}$ For this proposal, see Bréhier vol. 6.2: 44; Thaler 2011: 164-5; and Hadot 1988: 197-9. Hadot takes Plotinus to exclude the existence of (future) contingents in nous by way of the argument below (lines $45 \mathrm{ff}$.) for the thesis that all things nous knows are simultaneously present to it (“... le Dieu ne peut raisonner parce qu'il n'y a pas pour lui de choix possible, c'est-à-dire parce que tout est en lui présent de manière simultanée."). Hadot's construal of the development of the passage relies on reading the sentence at lines 42-45 as the question of whether nous exhibits foresight rather than as the assertion that it does (cf. Gurtler 2002: 112). But this is linguistically difficult, given the adversative force of the phrase (oủ $\mu \grave{\eta} v \dot{\alpha} \lambda \lambda \dot{\alpha}$ ) that introduces the next argument (see Denniston: 28-30; Smyth $\S 2767$ ['nevertheless']; Kühner-Gerth II, §534.7 ['jedoch']) and serves to announce Plotinus' intention to qualify the sense in which nous can be said to exhibit foresight.

${ }^{21}$ One might be tempted to read Plotinus' claim that the 'the future' is already present in nous as the stronger claim that nous actually has knowledge of future states of affairs here. Plotinus' epistemological commitments however tell against this stronger reading: given that nous' knowledge is not of sensible reality (see $\mathrm{C} 1$ ), it cannot strictly
} 
Finally, Plotinus presents a fifth argument (VI.7.3.1 ff.) against the proposal that certain features of the sensible world might be the products of planning that 'supplements' (prostheinai, VI.7.2.54) what is already given in the Forms, on the grounds that such supplemental planning is incompatible with the eternity of the world (C3). ${ }^{22}$ As noted above, Plotinus elsewhere points out the difficulty in thinking that an eternally existing cosmos was pre-planned, since there was no time before the cosmos existed when it could have been planned out. Here he builds on this difficulty by confronting the proponent of a planned cosmos with two further problems as to the circumstances in which the alleged planning occurred. On the one hand, if the cosmos has always been optimally arranged in accordance with an already existing divine plan, then a divine craftsman could only engage in planning - that is, in the formulation or discovery of a plan for the cosmos - if he had somehow forgotten that previously implemented plan. ${ }^{23}$ But if on the other hand the divine plan is a plan to remedy pre-existing deficiencies in the cosmos, then we will be unable to explain why this improvable cosmos had not previously been improved, since there was (ex hypothesi) a beneficent cause of good already present to it. Thus, god could relate to an eternal cosmos via planning only at the cost of being cognitively imperfect or imperfectly good; neither of which alternatives is acceptable. It is worth noting that this final argument also excludes the possibility that some divine entity other than nous (e.g. the World Soul or the 'lesser gods' of the Timaeus) could be responsible for planning permanent features of the cosmos; for the same problems can be posed for any such entity. ${ }^{24}$

speaking know future states of affairs in the sensible world. Contrast e.g. Boethius' God, whose knowledge is completely and eternally present to him, and embraces all states of affairs in the sensible world-past, present, and future (De cons. 5.6.1-17).

${ }^{22}$ Thaler 2011: 165-6 rightly notes that the argument targets the idea that creation of sensible kinds involves supplementing features given by the Forms with 'additions or alterations'. The opening lines of the chapter (ln. 1-3) may well adumbrate a further criticism of supplemental planning in particular, viz. that such planning of structures here would be counterproductive, as it could only serve add or subtract features given in the Form, and so, reduce the product's conformity to its intelligible model.

${ }^{23}$ That is, if he forgot the plan specifying how Forms should be instantiated; contra Hadot 1988: 206, the problem envisaged is not that of fallen Demiurge (à la the Gnostics) who must plan because he has forgotten the Forms. See preceding note.

${ }^{24}$ Indeed, Plotinus elsewhere stresses that the World-Soul (and Nature) do not deliberate or plan, but rather reflect on thought-contents that derive ultimately from divine nous (IV.4.10.6-18; IV.4.11.1-13; IV.4.12.1-29; IV.8.8.1316), a fact that underlies Plotinus' decision to characterise their mode of thought as theôria (III.8.1 ff.). Armstrong obscures this point in his translation of III.9.1 by construing the mental activity (dianoeisthai, cf. Tim. 39e9) whereby soul undertakes to reproduce what it sees in nous in the sensible cosmos as 'planning'. 
Plotinus' five arguments together constitute a robust case against divine planning of the sensible cosmos. Divine nous' nature implies that it (1) lacks appropriate starting points for thinking about the sensible world; (2) is not in a defective cognitive condition where planning would be necessary or appropriate; and cannot engage in the consideration of (3) alternatives or (4) prospective states of affairs as such, both of which are essential to planning. Furthermore, (5) the eternality of the world's structures is incompatible with these features being planned by gods. ${ }^{25}$ Plotinus accordingly suggests (VI.7.1.28-32) that the terms logismos and proorasis are properly used of divine nous to indicate that things here are arranged as someone who reasoned about them would have arranged them, not to indicate that god actually engages in logismos or literally "fore-sees" what happens here. This comment seems to be intended to legitimise Platonic ways of talking.

\section{Providence Without Planning}

What room is left for providence by Plotinus' claim that divine planning is impossible (and so a fortiori that it has no causal role in the ordering of the physical world)? Plotinus gives his clearest explanation of what he takes providence to be in III.2-3, On Providence, which comprises a continuous essay in theodicy. The main purpose of this text is to rebut the claim (put in the mouths of Epicureans and Gnostics) that our cosmos is not arranged in the best possible way for a thing of its kind. We shall have something to say below about his strategy for this rebuttal; what is of immediate interest is the 'position statement' that Plotinus stakes out near the outset of his discussion. He asserts that providence (pronoia) exists, but warns against understanding this assertion to entail that the cosmos has been ordered in accordance with divine deliberation or logismos. For the term 'pronoia' when applied to nous as the cause of the cosmos does not imply that nous is prior to (pro) the cosmos in time (and so that it gives fore-thought to the cosmos); indeed, the term does not imply divine thought about the cosmos at all. Rather, the term designates the metaphysical priority of nous to the cosmos (III.2.1.21 ff.; cf. VI.8.17.9-12);

\footnotetext{
${ }^{25}$ These considerations may not exhaust Plotinus' reasons for denying planning to nous. For example, since Plotinus' nous is, like Aristotle's, unchanging, it cannot engage in a step-by-step process of reasoning (Opsomer 2005: 84).
} 
or, as he puts it in what appears to be his official definition of pronoia, "providence [for the physical cosmos] is its being in accordance with nous" (III.2.1.21 f.). ${ }^{26}$

It is worth pausing to appreciate just how radically austere an account of providence this is. In asserting that divine providence has brought about the best physical cosmos possible, Plotinus explicitly refuses to ascribe any planning or supervisory capacity to divine nous with regard to that cosmos. For him, to speak of nous as pronoia is simply to point to its causal role vis-à-vis the cosmos; one might just as well say that the term properly refers to the katanoetic nature (as it were) of the physical world, that is, to the fact the contents and features of this world are causally determined by the Forms that nous contemplates.

It is in the very nature of the Forms to emanate forth from their own being, and in so doing to generate the physical world as a reflection and image of themselves. On the austere Plotinian picture, whatever exists here in our world is simply a necessary result of that emanation. Accordingly, the only form of explanation Plotinus will admit for the world's containing some given formal feature is "[in order] that there shall be everything" (VI.7.3.14 f.), i.e., because intelligible reality necessarily gets expressed as fully as possible here in its image (the sensible realm). So all things here are present here because they are already present there, among the Forms; but, again, they are not present either here or there through divine planning. The benefit and welfare of the inhabitants of the physical universe were not (and could not possibly have been) taken into account in its creation. ${ }^{27}$

\section{Problems for Plotinian Providence}

This view of providence, according to which all formal features of the sensible cosmos have counterparts in nous, faces certain difficulties. To begin with, Plotinus himself identifies

\footnotetext{
${ }^{26}$ In line with this definition, the World Soul exercises providence in a derivative way, by communicating the contents of nous to the sensible world (III.3.4; IV.8.2).

${ }^{27}$ It has been proposed that Plotinus' austere theory of providence may owe a debt to Alexander's. For Alexander, providence is exercised over the sublunary region by the heavens, whose orderly motions ensure regular processes of generation and destruction as well as the permanence of species kinds (Quaestio 1.25 41.4-19 and 2.19 63.10-28 Bruns; De Prov. 33.1f., 87.5ff. Ruland). Alexander's view that providence involves no planning anticipates a key aspect of Plotinus' position, but his view as stated accords no prominent role to divine thought. In particular, it is not clear whether, for Alexander, divine nous itself (i.e. the Prime Mover) exercises providence (for a negative answer, see Sharples 1982: 200-4); or whether Alexander takes the contents of divine thought to determine the structure of the cosmos or the natural kinds within it, as Plotinus does. For Alexander, see Sharples 1982, and, for his possible influence on Plotinus, Thillet 2003: 46-54, and Chiaradonna 2015 in this volume.
} 
two aporiai to the effect that nous' possession of such counterparts is incompatible with the perfection of its thought. It is moreover unclear how to explain the fact that nous contains counterparts of structures here in the sensible world that seem optimised for the survival of living creatures, given that (on Plotinus' theory) nous is precluded from giving any thought to the conditions of embodied life.

Let us begin with the two aporiai Plotinus himself discusses.

First, since nous has counterparts of all things here, there must be a counterpart of senseperception in the Form of Man. But if sense-perception, a non-rational cognitive capacity, itself has a counterpart in nous, then this threatens to involve nous with a cognitive activity inferior to the theôria which alone is proper to it (VI.7.3.22-33; VI.7.4-7). Plotinus addresses this difficulty by insisting that the noetic counterpart of sense-perception is not a capacity to apprehend senseobjects. As designations such as 'fire' or 'horse' are not applied synonymously to the Forms and their participants, Plotinus can reasonably deny that the existence of 'perception' in nous straightforwardly implies its possession of a capacity to apprehend sense-objects. Moreover, since the capacity to perceive sense-objects would be incompatible with nous' nature as a pure intellect, Plotinus has a positive reason to insist that this feature of 'perception' here does not apply to the noetic counterpart of the same name. Plotinus thus accepts that there must be a counterpart of sense-perception in nous that serves as an analogue for the cognitive faculty here that is essentially related to sense-objects, without itself standing in a cognitive relation to senseobjects. To explain how this might be possible, Plotinus proposes that the relation of our nonrational faculty of sense-perception to perceptible bodies has its analogue in our rational soul's cognitive relation to the noetic counterparts of 'bodies' or 'sensibles'-presumably, what is meant here are those Forms that correspond to sensible bodies here, e.g. the Form of Fire ${ }^{28}$ whereas the rational soul's cognitive relation to Forms in nous has as its analogue the cognitive relation of the Form of Man to itself (VI.7.6.1-12; VI.7.7.19-31). ${ }^{29}$ With this proposal, Plotinus suggests that counterparts for non-rational faculties can be found in nous without nous itself being saddled with non-theoretical capacities.

\footnotetext{
${ }^{28}$ For the suggestion that 'bodies' and 'sensibles' in nous are to be so understood, see Emilsson 1988: $360-363$.

${ }^{29}$ There is a question here about how the cognitive relation of the Form of Man to itself serves to prefigure rational soul's cognitive relation to a plurality of Forms. The answer may lie in Plotinus' view that each Form, in thinking itself, also thinks other Forms, apparently because its comprehensive self-knowledge requires an understanding of how it relates to other Forms.
} 
Second, there is the aporia that the perfection of nous will apparently be compromised if it contains noetic counterparts of inferior sensibles (e.g. 'worthless' [eutelês] non-rational animals; VI.7.8.15-18, VI.7.9.1-5). Plotinus' initial line of response to this difficulty is to point out that the counterparts of non-rational animals must (in accordance with his theory of nous) be intellects and so, far from being worthless, very fine indeed. But he concedes that these intellects are presumably inferior to those intellects within divine nous that correspond to rational animals. This response shifts Plotinus' burden to showing that the existence of such inferior intellects in nous is consistent with its optimal condition overall. And Plotinus thinks this burden can be met by contending that the inclusion of these inferior intellects in nous contributes to its perfection by making it complete ('teleios', 'pantelês'; VI.7.10.4-7; VI.7.12.1-4). ${ }^{30}$

This appeal to completeness might look like an ad hoc solution to the problem at hand, but in fact, the view that the completeness of nous involves an extensive plurality of inferior Forms has a firm basis in the principles governing nous' constitution. ${ }^{31}$ On Plotinus' theory, there are relations of priority and posteriority within the contents of nous (e.g., each genus is prior to its subordinate species), and inferior Forms are a necessary outcome of successive stages in the articulation of nous' contents (VI.7.9.15-20). However, even though these articulations bring with them some Forms that are (taken individually) inferior to others, Plotinus has a principled explanation of why such articulations are intrinsic to nous' nature. He contends that an object of thought must have some complexity, and so, that some degree of composition in the object of thought is a minimal condition on nous' thinking. But what is crucial for present purposes is that Plotinus also takes the minimal differentiation required for thought to presuppose a principle responsible for maximal differentiation within nous.

If it [i.e. nous] has no change in it, and no 'difference' wakes it to life, it would not even be an activity.... Now certainly what has come to be has come to be from the same and the different; and not just any different, but universal difference; for its same is also universal. But since it is all that is same and all that is different, there is no one of the others that it leaves out. Its nature therefore is to become different in every way. (VI.7.13.11-12, 21-25)

\footnotetext{
${ }^{30} \mathrm{Cf}$. the characterization of the model as a "complete living being" at Tim. $31 \mathrm{~b}$.

${ }^{31}$ For these principles, see Rappe 2002, Emilsson 2007: 160-4, and Thaler 2011.
} 
In this passage, Plotinus alludes to his interpretation of the five 'greatest kinds' at Plato's Sophist 254b-55e-being, sameness, difference, motion, rest-according to which these generic 'kinds' serve as primary principles explaining the nature and constitution of nous (II.4.5; V.1.4; VI.2.79). On this interpretation, 'difference' is the cause not just of the minimal differentiation in the object of thought required for thinking, but also - apparently, because 'difference' is universal in scope - of comprehensive differentiation in nous' object. So, on Plotinus' theory, it follows from the basic principles of divine thought that there will be comprehensive differentiation among nous' objects of thought. Thus, Plotinus can reasonably insist that maximal internal diversification, together with the existence of inferior Forms it implies, is necessary to the completeness of nous' nature. ${ }^{32}$

Thus far, we have focused on a pair of difficulties for the perfection of divine thought that Plotinus sees as arising from the thesis that all formal features of the cosmos are prefigured in nous. But this thesis might be thought to involve a further problem, one that presents a significant obstacle to regarding Plotinus' theory as a respectable alternative to the natural teleology of Aristotle or the Stoics. According to those models of natural teleology, the perfection of individual species and the good order of the sensible cosmos as a whole are to be explained by reference to the choiceworthy ends their features subtend. Plotinus by contrast maintains that although the sensible cosmos and the species within it are optimally constituted, their features are fully determined by the contents of a divine mind that cannot take consideration of the natural world or of ends internal to that world. How then can Plotinus explain the fact that nous possesses those very thoughts that ensure a well-ordered physical cosmos and well-adapted organisms, given that it cannot (ex hypothesi) give any thought to the sensible cosmos and the conditions of embodied life? If we concede to the Platonist that divine nous cannot think about, for example, the utility of eyes and horns for organisms here, can he still tell a plausible story about how nous entertains thoughts that guarantee the existence of such useful structures here? Plotinus is clearly optimistic that nous' thoughts ensure an optimal cosmos, albeit without fully explaining the grounds for his confidence. In what follows, we will argue that his presentation of his theory does suggest one important reason for this optimism.

\footnotetext{
${ }^{32}$ Compare Thaler 2011: 177-9, who proposes that the diversity of living Forms serves the teleological purpose of supplying all necessary parts of "the general notion of life" (178). He rightly calls attention to evidence that, for Plotinus, each Form contributes to the 'completeness' of nous' life; less clear is whether Plotinus means by this (as Thaler proposes) that life is a genus whose existence is dependent on that of all its sub-species.
} 
It will be helpful to begin by drawing a distinction between two different possible ways of conceiving of the noetic counterparts of things here. On the one hand, Plotinus might think that nous contains more or less detailed blueprints for each of the structures here; for example, the noetic counterpart of 'horn' in the Form of bull might be a specification for a pointy keratinous protuberance of the skull of a certain shape and relative size (Option 1). But this suggestion is problematic. It is hard to see how nous could be in a position to conclude that just this sort of structure is necessary for the completeness of the Form of Bull, given that nous is (ex hypothesi) precluded from thinking about the conditions here that make the desirability of a structure with just these features intelligible (e.g. defense against predators or competition with other members of the herd). On the other hand, Plotinus might think that the noetic counterpart of 'horn' does not contain a detailed articulation of the features of horn we find here; rather 'horn' in nous is something that has a function in nous analogous to that of horn here, while the structural features of horn here only emerge in the process of emanation (Option 2). We will now adduce some textual evidence that lends some support to Option 2, and then consider how Option 2 helps Plotinus avoid the problem raised for Option 1.

As mentioned above, Plotinus appears to hold that the noetic counterpart of the senseperceptual apparatus in humans is constituted simply by the cognitive relation of the selfthinking Form of Man to itself. Similarly, when Plotinus discusses the noetic counterparts of horns and claws, he asserts that these are not for defense (a Form, after all, doesn't need to defend itself), but rather serve to make the Form in question self-sufficient (autarkês) and complete (teleios) as the kind of 'living being' (zôon) it is, viz. as the theoretical intellect in question (VI.7.9.39-10.7). The notion that 'horns' and 'claws' make the Forms in question complete is neutral as to what the Form thinks in having these elements. But there is no suggestion that 'horns' and 'claws' are otherwise like the structures of the same name in the sensible world, and Plotinus' treatment of the noetic counterparts of sense-perception (discussed above) tends to count against the suggestion that they are. So what we seem to find in nous corresponding to claws and horns are features that play the functional roles of providing intelligent life, self-sufficiency, and completeness to the Forms, rather than blueprints for whatever bodily structures or psychic faculties might best serve to realise the analogues of these excellent divine attributes in the sensible world. If this is right, then Plotinus is not committed to the implausible position (Option 1) that nous works out in detail structures that will turn out to 
have utility here without taking into consideration the conditions and ends here with reference to which these structures have utility.

But if the physical structures of such features as 'eye' and 'horn' are not already worked out in nous, as Option 2 would have it, then how do features of nous ensure the existence of such useful structures here? Presumably, the answer must be that these features in the sensible world come into existence automatically (as it were) as images of the Forms generated though the process of emanation. This is not as uninformative a solution as it might seem. Once we accept the assumption that the Forms cause (but do not contain detailed specifications of) optimal physical structures, the emergence of such structures in the sensible cosmos is secured by the Platonist assumption that Forms cause their sensible participants to approximate to the Forms' own perfections. Plotinus can be confident that every species here will turn out to be a successful design, since it will necessarily possess whatever physical structures replicate (as far as is possible in the physical medium) the completeness, self-sufficiency, and vitality of the Form of which it is a likeness.

\section{A Theory of Providence?}

Earlier we observed that Plato characterizes the Demiurge's thought in relation to the physical cosmos as 'providence' (pronoia) because the organization and features of the cosmos are planned out in advance by the Demiurge. Given Plotinus' categorical denial that the Platonic Demiurge in fact has any plans or concerns whatsoever regarding the cosmos (let alone any with temporal priority to it), one might reasonably wonder how he manages to take his theory about the causal relationship between divine nous and the physical world to constitute an account of providence at all. ${ }^{33}$ Plotinus no doubt feels some obligation to maintain that the world is under the control of providence simply in order to remain exegetically faithful to Plato's assertions about pronoia, and this represents one motivation for his efforts to show that the application of the term 'pronoia' to divine nous is justified. Thus far, we have seen that Plotinus legitimates Plato's ascription of pronoia to the Demiurge in two ways: (1) pronoia is nous' being causally (but not temporally) prior to (pro) the cosmos; and (2) nous can be said to have foresight in the

\footnotetext{
${ }^{33}$ Cf. Atticus' complaint that Aristotle, like the Epicureans, effectively does away with providence by denying that the gods are interested in human affairs (fr. 3 des Places).
} 
sense that it eternally knows the noetic counterparts of what exists both earlier and later in time here in the sensible world. That is not the end of the matter, however; Plotinus has a further (and more substantial) rationale for framing some of his claims about nous as claims specifically about providence.

Divine pronoia is typically invoked by Plotinus' Platonist predecessors (as well as by the Stoics, who were also in part inspired by the Timaeus) precisely as an explanatory basis for the claims (a) that the cosmos is optimally organised and (b) that there is divine justice (i.e. the wicked do not go unpunished, nor the virtuous unrewarded). ${ }^{34}$ So if Plotinus can show that divine intellection (as he characterises it) guarantees the truth of both (a) and (b), then he can fairly claim to have delivered a story about 'providence' to rival those traditional theories that appeal to divine planning in order to support the same claims.

We have already seen above how Plotinus takes himself to have established (a): all of the formal features of natural entities (including those which enable animals to survive and flourish, each in its own way) are given in the intelligible content of nous, which is also ultimately responsible for their generation (via emanation). It is worth emphasizing that Plotinus will say the same thing about the entire physical cosmos itself, taken as a whole: it is the grand product of the emanation of the Forms taken together as a whole, and this is precisely what ensures that it is optimally organised. In III.2.1, Plotinus characterises the Forms collectively as constituting the 'first and truest' cosmos on account of the fact that the relations that they bear to one another are completely harmonious, with no trace of conflict or disunity. This harmonious unity is instantiated in the relations among the various parts of the physical world-insofar as such unity can be instantiated in the latter's imperfect material medium - earning it too the title of 'cosmos' (III.2.2; cf. VI.8.14.25-28).

This justification of (a) amounts to a reinterpretation of the Platonic Demiurge: given that formal causes in nous are alone what determine the best possible state of affairs in the cosmos, the theoretic activity of divine intellect yields results that are just the same as — or perhaps even

\footnotetext{
${ }^{34}$ The association of these claims with the assertion of divine providence was not confined to philosophical circles, but enjoyed somewhat wider currency among educated Greeks. See for example Theon, Progymnasmata 126,3128,2 (Patillon), where (a) is invoked as a commonplace that an orator could draw upon in support of the thesis that "the gods have forethought (pronoousi) for the cosmos" (126,3-4); and Plutarch, De sera 549b-e, where doubt of (b) is presented as perennially leading some people to believe that there is no providence.
} 
better than - those that would have been brought about by optimal planning. ${ }^{35}$ In effect, the selfpropagating nature of the good precludes the need for divine benevolence understood as goodwill directed towards the world as such; the benevolence of nous on Plotinus' view just is its self-propagating nature, qua good.

As for (b), Plotinus pursues in III.2-3 a theodical strategy that derives in its broad contours from Book 10 of Plato's Laws. This strategy is too complex to discuss in detail here, ${ }^{36}$ but of special note for present purposes is Plotinus' claim (following Laws 904b-e) that the soul of every mortal after death is reincarnated or transposed into a new situation that reflects its 'worth' (axia), and that this new situation itself represents an appropriate reward or punishment for its character and conduct in life (III.2.13). Plotinus emphasises that this process of justice via reincarnation is built into the orderly arrangement of the world; it does not require special divine attention or intervention. ${ }^{37}$ So souls, which are themselves each co-eternal with the cosmos, are fully implicated in the cosmic order; every soul after death comes to be disposed in just the way necessitated by that soul's past lives. The career of every soul is in effect the expression of a law that is both unique to itself and part of a natural order that is as just as possible.

\section{Conclusion}

Plotinus rejects the traditional Platonist conception of the Demiurge of Plato's Timaeus, on which divine nous is understood to cause the physical world to be well-ordered (to be a fine kosmos) through deliberation or planning; as we have seen, he argues this conception of the Demiurge to be incompatible with certain important commitments (C1-3) that he thinks all Platonists should share. He offers an alternative account of divine providence that is interesting because of its very austerity. The physical world exists because the Forms necessarily produce it by emanation; and the physical world is well-ordered because it is necessarily the physical expression of the perfections of the Forms, in all their variety and mutual harmony. Plotinus

\footnotetext{
${ }^{35}$ See note 7 above.

${ }^{36}$ Plotinus borrows liberally from Stoicism in his theodicy as well; see Bréhier, vol. 3: 17-23.

${ }^{37}$ Claims about justice through reincarnation appear frequently in the Platonic myths (e.g. those in Gorgias, Phaedrus, Phaedo, and Republic 10), but Plotinus is apparently interested in a feature unique to the myth of Laws 10: the process of soul-relocation is there claimed to occur automatically and in accordance with general rules, so that the divine administration of the universe is accomplished, as Plato puts it, with "marvellous ease" (904a).
} 
urges us to interpret all Platonic talk of divine benevolence in terms of the former claim, and all Platonic talk of divine craftsmanship in terms of the latter.

Plotinus' account of the Demiurge's providential activity was to enjoy an influential but mixed legacy in Later Antiquity. ${ }^{38}$ While his position that the cosmos is not the product of divine planning would become the predominant view, his denial that the providential deity thinks about the sensible cosmos would prove to be too radical a thesis for many of his successors. On these points, Proclus is illustrative of broader trends. Proclus wholeheartedly accepts Plotinus' verdict that divine providence involves no deliberation or planning, and to this extent he endorses Plotinus' decisive turn away from the traditional Platonist view. ${ }^{39}$ On the other hand, Proclus is not prepared to follow Plotinus in his insistence that there is no knowledge of the physical world on the part of the providential deity. Rather, Proclus contends that providence entails knowledge of what falls within the scope of its oversight, and so, knowledge of physical reality, at the level not just of kinds but even of particular items and contingent events. ${ }^{40}$ Here Proclus' attempt to develop an epistemology capable of reconciling the transcendence and immutability of divine cognition with the idea that providence does involve thought about our cosmos reflects - at least implicitly - a partial acceptance and a partial rejection of Plotinus' remarkably austere and revisionary account of divine pronoia.

Bibliography:

Adamson, P. (2014). 'Freedom, Providence, and Fate,' in P. Remes and S. Slaveva-Griffin (eds.), The Handbook of Neoplatonism, Stockfield: Acumen (forthcoming).

\footnotetext{
${ }^{38}$ For providence in Later Neoplatonism, see Schibli 2002: ch. 3, Adamson 2014, and the introductions to Steel 2007 and Opsomer and Steel 2012.

${ }^{39}$ Proclus contends that gods and lesser divinities exercise providence without calculation (logismos, ET prop. 122; De dec. dub. 65).

${ }^{40}$ For Proclus, although the Demiurge proper continues to be situated at the level of divine nous (specifically, he is identified with Proclus' third triad therein, the 'intellective intellect'; for details, see Opsomer 2000: 116-119), providence is identified in the first instance with the beneficent activity of the henads, which are gods posterior to the One, but prior to nous (ET prop. 120, 134; De dec. dub. 66); see Proclus' etymology of 'pronoia' as 'prior to nous' (pro nou) (ET prop. 120; cf. Prov. 13). Lesser divinities also exercise providence, thanks to their participation in the henads (ET prop. 120; De dec. dub. 62 ff.). For the thesis that the henadic gods know particulars and contingents, albeit timelessly and non-contingently, see ET prop. 124; De dec. dub. 2-8; and In Parm. 4.952 ff., with Opsomer and Steel 2012: 5-16. For divine foreknowledge of particulars in Neoplatonist authors, see Sorabji 1983: 255-6.
} 
Armstrong, A. H. (1966-88). Plotinus Enneads. Text and translation with notes. 7 vols. Cambridge, Mass.: Harvard University Press.

Baltes, M. (1976-78). Die Weltentstehung des platonischen Timaios nach den antiken Interpreten. 2 vols. Leiden: Brill.

Bréhier, É. (1924-38). Plotin. Ennéades. Texte grec et traduction française. 7 vols. Paris: Les Belles Lettres.

Dragona-Monachou, M. (1994) 'Divine Providence in the Philosophy of the Early Empire,' in W. Haase (ed.), Aufstieg und Niedergang der Römischen Welt (ANRW) II 36.7, 4417-4490.

Emilsson, E. K. (1988). 'Critical Comments on John Dillon, 'The Mind of Plotinus', in J. Cleary (ed.) Proceedings of the Boston Area Colloquium in Ancient Philosophy 3, The University Press of America, 359-363.

(2007). Plotinus on Intellect. Oxford: Oxford University Press.

Gurtler, G. (2002). 'Providence: The Platonic Demiurge and Hellenistic Causality,' in M. F. Wagner (ed.), Neoplatonism and Nature: Studies in Plotinus' Enneads, New York: SUNY, 99124.

Hadot, P. (1988). Plotin. Traité 38 (VI,7). Introduction, traduction, commentaire et notes, Paris: Editions du Cerf.

Mansfeld. J. (1999), 'Alcinous on Fate and Providence,' in J.J. Cleary (ed.), Traditions of Platonism. Essays in Honour of John Dillon, Aldershot: Ashgate, 139-150.

Menn, S. (2001). 'Plotinus on the Identity of Knowledge with its Object,' Apeiron 34:3, 233-246. 
Opsomer, J. (2000), 'Proclus on Demiurgy and Procession,' in M. R. Wright (ed.), Reason and Necessity: Essays on Plato's Timaeus, London: Duckworth, 113-143.

(2005), 'Demiurges in Early Imperial Platonism,' in R. Hirsch-Luipold (ed.), Gott und die Götter bei Plutarch, Berlin: Walter de Gruyter, 51-99.

and C. Steel (2012). Proclus. Ten Problems Concerning Providence. London:

Duckworth.

Powers, N. (2013), 'Plato's Demiurge as Precursor to the Stoic Providential God,' The Classical Quarterly 63:2, 713-722.

Rappe, S. (2002), 'Explanation and Nature in Enneads VI.7.1-15,' in M. F. Wagner (ed.), Neoplatonism and Nature: Studies in Plotinus' Enneads, New York: SUNY, 71-98.

Schibli, H. S. (2002). Hierocles of Alexandria. Oxford: Oxford University Press.

Sedley, D. (2007), Creationism and Its Critics in Antiquity. Berkeley: University of California Press.

Sharples, R.W. (1982), 'Alexander of Aphrodisias on Divine Providence: Two Problems,' Classical Quarterly 32.1, 198-211.

(2003). 'Threefold providence: the history and background of a doctrine,' in R.

W. Sharples and A. Sheppard (eds.), Ancient Approaches to Plato's Timaeus, Bulletin of the Institute of Classical Studies: London, 107-127.

Sorabji, R. (1983). Time, Creation, and the Continuum, London: Duckworth.

Steel, C. (2007). Proclus: On Providence. London: Duckworth. 
Thaler, N. (2011). 'Traces of Good in Plotinus's Philosophy of Nature: Ennead VI.7.1-14,' Journal of the History of Philosophy 49:2, 161-180.

Thillet, P. (2003). Alexandre d'Aphrodise: Traité de la providence, Paris: Verdier. 